\title{
New Opportunities for Targeting the Androgen Receptor in Prostate Cancer
}

\author{
Margaret M. Centenera, ${ }^{1,2}$ Luke A. Selth, ${ }^{1,3}$ Esmaeil Ebrahimie, ${ }^{3}$ Lisa M. Butler, ${ }^{1,2}$ \\ and Wayne D. Tilley ${ }^{1,3}$ \\ ${ }^{1}$ Adelaide Medical School and Freemasons Foundation Centre for Men's Health, University of Adelaide, \\ Adelaide SA 5005, Australia \\ ${ }^{2}$ South Australian Health and Medical Research Institute, Adelaide SA 5001, Australia \\ ${ }^{3}$ Dame Roma Mitchell Cancer Research Laboratories, Adelaide Medical School, University of Adelaide, \\ Adelaide SA 5005, Australia \\ Correspondence: wayne.tilley@adelaide.edu.au
}

Recent genomic analyses of metastatic prostate cancer have provided important insight into adaptive changes in androgen receptor (AR) signaling that underpin resistance to androgen deprivation therapies. Novel strategies are required to circumvent these AR-mediated resistance mechanisms and thereby improve prostate cancer survival. In this review, we present a summary of AR structure and function and discuss mechanisms of AR-mediated therapy resistance that represent important areas of focus for the development of new therapies.

$P_{\mathrm{t}}^{\mathrm{r}}$ rostate cancer is the most common solid tumor in men, accounting for $21 \%$ of all cancers in the United States, and is the second-leading cause of male cancer-related death (Siegel et al. 2016). Localized prostate cancer can be cured with surgery and/or radiation therapy. For advanced, metastatic, or recurrent prostate cancer, treatment with androgen deprivation therapy (ADT) is the current standard of care, which exploits the fact that prostate cancer cells are exquisitely dependent on androgens and the androgen receptor (AR) for growth and survival (Huggins et al. 1941). ADT is a chemical form of castration that uses luteinizing hormone releasing hormone (LHRH) analogs to suppress testicular production of androgens by the hypothalamic-pituitary-gonadal axis. ADT can be used alone or in conjunction with competitive $\mathrm{AR}$ antagonists that act peripherally to prevent residual androgens binding the AR (Labrie 2011). Although initially effective, ADT eventually fails, and patients progress to an incurable and lethal stage of disease, known as castrationresistant prostate cancer (CRPC) (Scher et al. 2004; Attard et al. 2016).

For many years, the chemotherapeutic agent docetaxel was the only approved treatment option for CRPC (Tannock et al. 2004). The realization that $\mathrm{AR}$ is reactivated in CRPC and remains the primary therapeutic target for this disease led to the development of secondgeneration AR-targeting agents, abiraterone acetate and enzalutamide, which improve survival of CRPC patients (de Bono et al. 2011; Scher

Editors: Michael M. Shen and Mark A. Rubin

Additional Perspectives on Prostate Cancer available at www.perspectivesinmedicine.org

Copyright (C) 2018 Cold Spring Harbor Laboratory Press; all rights reserved; doi: 10.1101/cshperspect.a030478

Cite this article as Cold Spring Harb Perspect Med 2018;8:a030478 
M.M. Centenera et al.

et al. 2012). Abiraterone inhibits androgen biosynthesis in the testes and adrenals and within prostate tumor cells by blocking cytochrome P450 (CYP17A1), a critical enzyme for testosterone synthesis (Potter et al. 1995; O'Donnell et al. 2004; Attard et al. 2005). Enzalutamide is a new-generation AR antagonist with greater potency than first-generation agents (Tran et al. 2009). The therapeutic landscape for CRPC broadened even further with recent approvals of cabazitaxel (second-line chemotherapy), radium-223 (bone-targeted radiopharmaceutical), denosumab (anti-RANK ligand monoclonal antibody), and sipuleucel-T (immunotherapy). However, despite the past decade of therapeutic revolution, the fact remains that none of these agents improve survival by more than a few months on average. Moreover, in the majority of cases in which second-generation AR-targeting agents or chemotherapies have failed, AR remains the key driver of disease (Karantanos et al. 2015). Thus, discerning the mechanisms by which AR continues to signal in the face of therapy is critically important.

This review provides an overview of AR structure and function and the key structural alterations in the AR gene and protein associated with resistance to ADT. Areas of research that represent key opportunities for more effective targeting of $\mathrm{AR}$ in prostate cancer are discussed.

\section{ANDROGEN RECEPTOR STRUCTURE AND FUNCTION}

The AR is an intracellular ligand-activated transcription factor that mediates the biological actions of androgens (Evans 1988). As a member of the steroid receptor subfamily of nuclear receptors (Lu et al. 2006), the AR shares structural and functional homology with the glucocorticoid, mineralocorticoid, progesterone, and estrogen receptors (Germain et al. 2006). The human $A R$ gene is located on the $\mathrm{X}$ chromosome at Xq11-12 and is organized into eight exons (Fig. 1A) (Brinkmann et al. 1989). The 90-kb gene encodes a $110-\mathrm{kDa}$ modular protein of 919 amino acids that is organized into four distinct functional domains (Fig. 1A) (Lubahn et al. 1988; Tilley et al. 1989): the ligand-binding domain (LBD), hinge domain, DNA-binding domain (DBD), and amino-terminal domain (NTD).

The LBD folds into $12 \alpha$-helices to form a ligand-binding pocket that mediates androgen binding (Matias et al. 2000; Sack et al. 2001) and is the target site of all clinically used AR antagonists. Upon ligand binding, the AR adopts an active conformation that induces formation of an AF-2 activation domain (He et al. 2004). Unlike the other steroid receptors, whose AF-2 surface is the primary site of interaction with coregulator proteins (Danielian et al. 1992; Heery et al. 1997), the AR AF-2 preferentially interacts with FXXLF motifs in the amino terminus of AR (Ikonen et al. 1997; Berrevoets et al 1998; Langley et al. 1998; Schaufele et al. 2005). This so-called N/C interaction facilitates cross talk between receptor domains that is critical for receptor stabilization, reduced ligand dissociation, and enhancing DNA-binding affinity ( $\mathrm{He}$ et al. 2000; He and Wilson 2002). The AF-2 domain can recruit specific AR coregulatory proteins containing FXXLF and LXXLL motifs that contribute to receptor function ( $\mathrm{He}$ et al. 2002). Linking the LBD to the DBD is a small, flexible hinge region, which contains a bipartite nuclear localization signal (NLS) that is exposed on ligand binding and mediates interaction with importin- $\alpha$ to translocate AR from the cytoplasm into the nucleus (Cutress et al. 2008). The hinge is an important site for posttranslational modification of the receptor, including acetylation, ubiquitination, and methylation (Clinckemalie et al. 2012). The DBD is $\alpha$-helical in structure and contains two cysteine-rich zinc finger motifs that mediate receptor homodimerization and direct interaction with the major groove of DNA (Luisi et al. 1991; Schoenmakers et al. 1999; Shaffer et al. 2004) at specific recognition sequences known as androgen response elements (AREs), which are located in the enhancer and promoter regions of AR target genes (Claessens et al. 2001). The consensus ARE is comprised of two hexameric half-sites of the sequence $5^{\prime}$-TGTTCT-3' separated by a 3-basepair spacer (Claessens et al. 1996; Schoenmakers et al. 1999; Claessens and Gewirth 2004). The AR also binds DNA at ARE half-sites in collaboration with transcription factors such as FoxA1, 


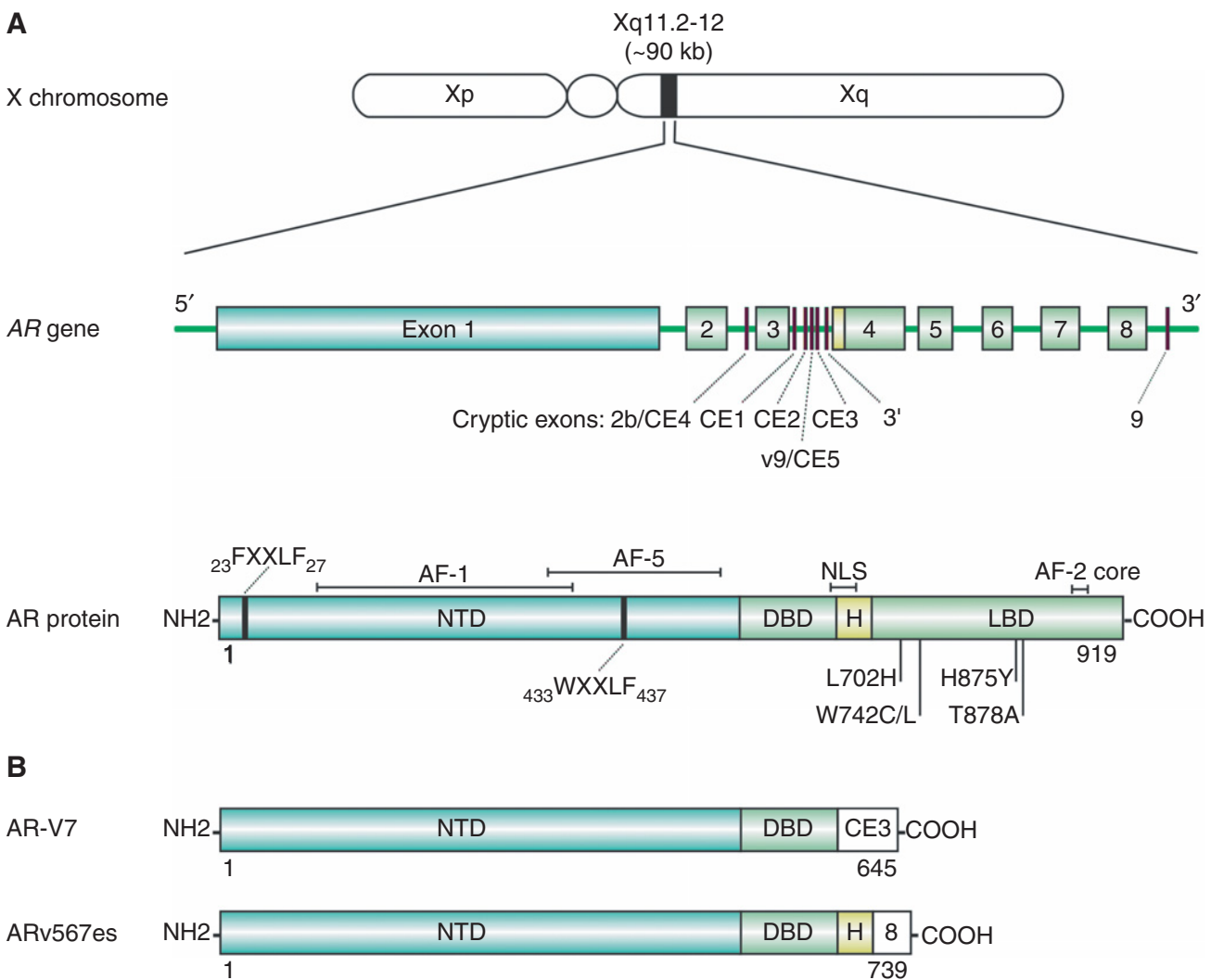

Figure 1. Chromosome, gene, and protein organization of the androgen receptor (AR) and AR variants. $(A)$ The human AR is encoded by a single gene located at Xq11-12 and is normally organized into eight exons, encoding a protein of $\sim 919$ amino acids. The full-length AR protein is divided into structural and functional domains: a large amino-terminal transactivation domain (NTD) containing activation function-1 (AF-1) and -5 (AF-5) and two LxxLL-like motifs ${ }^{23} \mathrm{FQNLF}^{27}$ and ${ }^{433} \mathrm{WHTLF}^{437}$, a DNA-binding domain (DBD), a small hinge region $(\mathrm{H})$ containing a nuclear localization signal (NLS), and a ligand-binding domain (LBD) containing activation function 2 (AF-2). Gain-of-function mutations in the $A R$ gene as a result of therapy-mediated selection pressure colocate to the LBD. Alternative splicing of cryptic exons (CEs) or exon skipping can give rise to carboxy-terminally truncated AR isoforms. (B) Structure of two clinically relevant AR-Vs, AR-V7 and ARv567es.

GATA2, and Oct1 that facilitate access of AR to the chromatin (Bolton et al. 2007; Massie et al. 2007; Wang et al. 2007; Lupien and Brown 2009). The AR amino-terminal domain (NTD) mediates the majority of AR transcriptional activity through two activation domains (AF-1 and $\mathrm{AF}-5)$ that recruit complexes of coregulators (Chmelar et al. 2007; DePriest et al. 2016) and the basal transcriptional machinery (Jenster et al. 1995; McEwan and Gustafsson 1997; Shang et al. 2002) to regulate the expression of AR target genes (Glass and Rosenfeld 2000; Ra- chez and Freedman 2001). Whereas the LBD and DBD are highly conserved and structured regions of the AR, the NTD has limited stable secondary or tertiary structure and is considered an intrinsically disordered protein domain, which presents challenges for therapeutic targeting of this domain. Despite its general lack of structure, the NTD does fold on interaction with coregulators or DNA, the conformation of which is dictated by the particular binding partner or DNA sequence (Kumar et al. 2004; Brodie and McEwan 2005). 
M.M. Centenera et al.

\section{ANDROGEN RECEPTOR MATURATION AND FOLDING}

Newly synthesized AR undergoes a highly ordered maturation process facilitated by the molecular chaperones' heat shock protein (HSP)70 and HSP90, and their cochaperones, to be correctly folded into its high-affinity ligand-binding form (Pratt and Toft 2003). Following synthesis, $\mathrm{AR}$ is rapidly bound by the cochaperone HSP40 to prevent aggregation of the unfolded receptor (Fan et al. 2003). HSP40 recruits HSP70 and stimulates its ATPase activity, allowing HSP70 to bind and deliver AR to HSP90 via the HSP organizing protein (HOP) (Chen and Smith 1998; Hernandez et al. 2002). HOP is one of many cochaperones that contain a tetratricopeptide repeat (TPR) domain; a protein-protein interaction surface characterized by three or more TPR motifs of a degenerate 34 amino acid sequence (Scheufler et al. 2000). Through its TPR domain, HOP binds to a highly conserved MEEVD sequence in both HSP70 and HSP90 to transfer AR from one chaperone to the other through a process that is still relatively uncharacterized (Chen et al. 1998). HSP90 binds as a homodimer directly to AR through the ARLBD and assembly of this receptor-chaperone heterocomplex induces the ATP-bound "closed" form of HSP90 (Pratt and Toft 1997), which is stabilized by the cochaperone p23 (Dittmar et al. 1997; Morishima et al. 2003). The presence of ATP weakens the affinity of HSP90 for HOP, and the HOP-HSP40-HSP70 complex is displaced by any one of several TPR cochaperones, known as immunophilins (Carrello et al. 1999). Members of the immunophilin family, including TPR-containing proteins FKBP51, FKBP52, CYP40, or PP5, display peptidyl-prolyl-isomerase (PPIase) activity that promotes AR-HSP90 heterocomplex assembly (Ni et al. 2010). The intrinsic ATPase activity of HSP90 together with the PPIase activity of the immunophilins fold AR into its functionally mature state by opening the AR ligand-binding pocket to make it accessible to androgens (Fang et al. 1996; Grenert et al. 1999; Ni et al. 2010). The mature AR is maintained in the cytoplasm in a heterocomplex that includes cochaperone SGT $\alpha$, which anchors the receptor to cytoskeletal microtubules and actin filaments (Buchanan et al. 2007; Trotta et al. 2012); immunophilins, which link AR to the dynein motor protein (Galigniana et al. 2002; Harrell et al. 2002); and HSP90 and its cochaperones, which protect $\mathrm{AR}$ from degradation and hold it in a ligand-inducible state (Pratt and Toft 1997). In the absence of ligand, FKBP51 is the major immunophilin in the AR-HSP90 complex. Binding of cognate ligand to the AR results in displacement of FKBP51 by FKBP52, which facilitates trafficking of $\mathrm{AR}$ along microtubules into the nucleus via retrograde movement of the dynein motor complex (Buchanan et al. 2007; Galigniana et al. 2010).

\section{STRUCTURAL CHANGES TO THE AR AS CASTRATION RESISTANCE MECHANISMS}

The failure of ADT to achieve durable inhibition of prostate tumor growth was previously attributed to an outgrowth of tumor cells that were androgen-independent and no longer required AR signaling for survival. However, it is now recognized that prostate cancer cell "addiction" to the AR is manifested in adaptive changes that ensure persistent AR signaling in the face of ADT (Knudsen and Scher 2009). This concept formed the basis of a drug screen that identified the now widely used AR antagonist enzalutamide (xtandi), which was undertaken in prostate cancer cell lines engineered to express high levels of AR to reflect this common clinical scenario (Tran et al. 2009). Similar research has led to the identification of newer AR antagonists including ARN-509 (Clegg et al. 2012) and ODM201, both of which are currently in phase III clinical testing (see Clinicaltrials.gov identifiers NCT01946204, NCT02489318, NCT02531516, NCT02200614, and NCT02799602).

The most recent, large-scale genomic analysis of CRPC suggests that $>70 \%$ of CRPC cases harbor AR pathway aberrations, consistent with adaptive changes to maintain AR activity (Robinson et al. 2015). Understanding how these aberrations drive AR signaling in the castrate environment remains a major research focus. 
Targeting the Androgen Receptor in Prostate Cancer

\section{$A R$ Gene Amplification}

The first studies of AR pathway aberrations showed genomic amplification of the $A R$ locus in up to $30 \%$ of recurrent primary or castrationresistant prostate tumors, with little or no amplification detected in untreated prostate cancer (Visakorpi et al. 1995; Koivisto et al. 1997; Bubendorf et al. 1999; Linja et al. 2001). More recent studies, using whole-exome sequencing or targeted sequencing of cell-free DNA in metastatic CRPC, indicated that AR gene amplification emerges more frequently than previously estimated, occurring in $45 \%-60 \%$ of cases (Taylor et al. 2010; Grasso et al. 2012; Carreira et al. 2014; Robinson et al. 2015; Wyatt et al. 2016), and is associated with therapeutic resistance and poorer overall and progression-free survival (Romanel et al. 2015; Salvi et al. 2015; Wyatt et al. 2016). The increase in AR mRNA and protein levels that result from $A R$ gene amplification has been shown to sensitize prostate cancer cells to castrate levels of androgens (Visakorpi et al. 1995). Moreover, using isogenic prostate cancer xenograft models, Chen and colleagues showed that increased $A R$ mRNA was the primary change in the progression to castration resistance and was sufficient for resistance to castration or the AR antagonist bicalutamide (Chen et al. 2004).

\section{AR Gene Mutations}

The first indication that $A R$ mutations may contribute to castration-resistance came from studies of the AR-dependent prostate cancer cell line, LNCaP (Wilding et al. 1989; Veldscholte et al. 1990; Culig et al. 1999). A single point mutation, T878A (originally reported as T877A), in the AR-LBD of LNCaP cells confers AR activation not only by androgens but also progestins, estrogens, glucocorticoids, and certain AR antagonists (hydroxyflutamide, nilutamide, bicalutamide). This phenotype, known as ligand promiscuity, facilitates AR activation in a low-androgen environment. Efforts to define the frequency of somatic $A R$ gene mutations in prostate cancer have revealed that they are rare in primary disease but emerge in tumors pro- gressing on ADT or following second-line hormonal manipulations, supporting the notion of clonal selection during treatment (Gundem et al. 2015). Early studies using PCR-based methods identified more than 85 mutations in clinical prostate cancer that occur within distinct regions of the AR NTD, hinge, and LBD (McPhaul et al. 1991; Suzuki et al. 1993; Taplin et al. 1995; Tilley et al. 1996; Buchanan et al. 2001; Gottlieb et al. 2004; Steinkamp et al. 2009). The biological consequence of these mutations was attributed to their location, with ARLBD mutations conferring ligand promiscuity and AR-NTD mutations enhancing AR transactivation capacity through altered coregulatory interactions (Buchanan et al. 2001; Gottlieb et al. 2004). In contrast to these early findings, recent next-generation sequencing efforts have identified few mutations within the AR-NTD and instead ascribe the LBD as the primary mutational hotspot in CRPC, with a reported incidence of up to 20\% (Taylor et al. 2010; Barbieri et al. 2012; Grasso et al. 2012; Robinson et al. 2015). The T878A mutation present in LNCaP cells is one of the most frequent clinically observed $A R$ mutations. In addition to conferring agonist activity to first-generation AR antagonists, the T878A mutation also converts second-generation antagonists enzalutamide and ARN-509 into partial agonists (Lallous et al. 2016) and has been identified in patients progressing on abiraterone (Azad et al. 2015a; Romanel et al. 2015). Other AR mutations frequently observed across clinical studies include $\mathrm{L} 702 \mathrm{H}, \mathrm{W} 742 \mathrm{C} / \mathrm{L}$, and H875Y, all of which confer resistance to AR antagonists, abiraterone, and/or hydrocortisone to facilitate castration resistance (Fig. 1A) (Lallous et al. 2016).

\section{AR Splice Variants}

AR splice variants (ARVs) derived from mRNA species that lack part or all of the exonic sequence encoding the LBD can be grouped into two broad classes: (1) truncated owing to the incorporation of a cryptic exon (CE); or (2) exon skipping events (Fig. 1B). $A R V$ mRNAs were first identified in cell lines but have since been detected in patient specimens, with recent RNA-seq data indicating the presence of at least 
M.M. Centenera et al.

16 distinct $A R V$ mRNA species in primary prostate cancer (The Cancer Genome Atlas Research Network 2015) and 23 in metastatic CRPC (Robinson et al. 2015). However, it must be noted that only two variants, AR-V7 and ARv567es, have been definitively detected at the protein level (Efstathiou et al. 2015; Qu et al. 2015; Welti et al. 2016; Henzler et al. 2016). This is partly caused by the dearth of ARV-specific antibodies but also the fact that abundance of ARVs is likely much lower than the full-length receptor, with an early study suggesting that AR-V7 and ARv567es mRNAs are present at $\sim 0.03 \%-7 \%$ of the fulllength receptor in CRPC bone metastases (Hornberg et al. 2011). A subsequent study validated this finding for AR-V7, suggesting that it is expressed at $\sim 5 \%$ of the levels of the canonical $A R$ transcript in CRPC (Robinson et al. 2015).

The combination of constitutive receptor activity with the absence of a functional LBD renders ARVs resistant to conventional ADT (Chan and Dehm 2014). This has led to the obvious hypothesis that these variants play a critical role in driving CRPC. Whereas ARVs have been shown to be required for castrate-resistant growth in various models (Chan et al. 2015), their clinical relevance has been harder to decipher (for a recent summary of this topic, see Luo et al. 2017). This is, at least, in part attributed to the aforementioned difficulty in detecting ARV proteins. Recent progress in this area, such as the analytical and clinical validation of an AR-V7 IHC method (Welti et al. 2016), suggests that this particular issue will ultimately be overcome. Nevertheless, the clinical significance of ARVs as a resistance mechanism in CRPC will remain equivocal until ARV-specific drugs are developed (Sharp et al. 2016).

Although the role of ARVs as a key driver of CRPC remains to be definitively resolved, recent findings have shown the utility of AR-V7 as a marker that predicts lack of response to ARtargeted therapies in CRPC. Antonarakis and colleagues (2014) first showed that men with detectable expression of AR-V7 mRNA in circulating tumor cells (CTCs) had lower response rates to enzalutamide and abiraterone. Since that time, numerous studies have verified the capacity of AR-V7 mRNA to predict response to these
AR-targeted therapies (for review, see Li et al 2017); moreover, an AR-V7 protein immunofluorescent assay on the Epic Sciences CTC detection platform developed by Scher and colleagues (2016) had similar predictive capacity. Importantly, the efficacy of chemotherapy is independent of AR-V7 expression in CTCs and other patient material (Antonarakis et al. 2015; Onstenk et al. 2015; Scher et al. 2016). Although AR-V7 clearly has great promise to guide treatment decision-making, key questions remain. First, the optimal method for measuring ARV7 (i.e., qRT-PCR, in situ hybridization, immuno-detection) and the most suitable source of patient material (i.e., CTCs, whole blood) remain to be determined (Luo et al. 2017). Second, results from a randomized controlled trial (NCT02269982) to prospectively evaluate the predictive utility of AR-V7 are not yet available. Finally, the presence of $A R$ mutations and/or copy number alterations in plasma cell-free DNA also provides predictive and prognostic information (Azad et al. 2015a; Wyatt et al. 2016); whether AR-V7 has greater and/or independent clinical utility compared with these genomic alterations remains to be determined. In short, the widespread application of AR-V7 as a tool to predict treatment response is far from assured. Nevertheless, given the estimate that AR-V7 testing in CRPC patients could result in savings of $\$ 150 \mathrm{M}$ per annum in the United States alone by reducing ineffective use of abiraterone and enzalutamide (Markowski et al. 2016), the ongoing interest in this potential biomarker application is clearly warranted.

\section{FUTURE PERSPECTIVES}

The recent evolution in understanding AR structure and function is facilitating new strategies to target this essential factor in prostate cancer. Below, we highlight fields of biology and therapy that we believe represent key areas of focus in the near future.

\section{Coregulators}

$\mathrm{AR}$ is regulated by a diverse and large suite of more than 300 protein coregulators that activate 
Targeting the Androgen Receptor in Prostate Cancer

(coactivators) or repress (corepressors) its activity (Chmelar et al. 2007; Heemers and Tindall 2007; DePriest et al. 2016). The complexity of this network is immense and is indicative of the extent and diversity of the coregulators with potential impact on AR function (Fig. 2); moreover, new coregulators continue to be identified (Paltoglou et al. 2017). As coregulators are essential for the transcriptional activity of $\mathrm{AR}$, it is not surprising that coregulator expression and activity is altered throughout the course of prostate cancer progression and in response to AR targeting therapies, with enhanced activity of coactivators and reduced activity of corepressors being a hallmark of CRPC (Chmelar et al. 2007; Heemers and Tindall 2007). We anticipate that the AR coregulator field will experience rapid progress in the next decade, facilitated by new methodologies and a better appreciation of their functional role in CRPC. For example, with the advent of more sensitive mass spectrometric methods for isolating protein:protein interactions (Mohammed et al. 2016), identification of additional AR coregulators associated with chromatin in specific disease states will be possible. Such methods will also allow robust comparisons of the protein "interactomes" of wild-type AR, and specific AR mutants and variants. Additionally, the power of integrative "omics"-incorporating cistromic, transcriptomic, genomic, and proteomic data, among others-will expedite identification of the coactivators that are critical for AR activity in castrate-resistant settings (Paltoglou et al. 2017; Stelloo et al. 2017).

As our understanding of AR coregulator biology continues to evolve, we believe that these factors will become a major class of therapeutic target in CRPC (reviewed in Biron and Bedard 2015; Foley and Mitsiades 2016). Considerable progress toward the development of small molecules that inhibit coactivator binding to the AR-NTD, AF-2 in the AR-LBD or binding function 3 in the AR-LBD has already been made (Lack et al. 2011; Munuganti et al. 2013; Myung et al. 2013; Ravindranathan et al. 2013). In many of these cases, the precise receptor binding surface for coregulators interacting with AR are unknown, limiting current efforts to develop drugs that modulate their function. We propose that integration of genome-wide technologies to define coregulator activity in critical diseasespecific contexts combined with rational drug design will accelerate this field. As an example of this workflow, an integrated transcriptomic/ kinomic approach identified the first kinase "chaperone" of the AR, choline kinase A (CHKA) (Asim et al. 2016). CHKA expression is associated with poor outcome, potentially because it is stabilizes the AR to enhance the AR signaling axis. This approach has high potential for rapid translation to the clinic because kinases are highly "druggable" (Fleuren et al. 2016).

\section{Chaperones}

The critical role of chaperones in AR maturation and signaling makes these proteins attractive therapeutic targets (reviewed in Azad et al. 2015b). This notion is supported by the significant focus to date on developing molecular inhibitors of HSP90 as novel agents for prostate cancer therapy (reviewed in Butler et al. 2015). Through binding the amino-terminal ATP-binding pocket of HSP90, inhibitors such as 17-allylamino-17-desmethoxygeldanamycin (17-AAG) and AUY922 prevent HSP90 from achieving its ATP-bound state and thus formation of the substrate-HSP90 complex (Prodromou et al. 1997; Janin 2010). Consequently, rather than being folded, AR and other HSP90 substrates are degraded by the ubiquitin proteasome pathway, a process that is fatal to prostate cancer cells (Solit et al. 2002; Williams et al. 2007; Centenera et al. 2012). Although HSP90 inhibitors have been in clinical development for prostate cancer for many years, one of the underlying issues is that agents currently in clinical trial, all of which inhibit the ATP-binding pocket, induce a resistance mechanism known as the heat shock response (Bagatell et al. 2000; Butler et al. 2015). The heat shock response, mediated by heat shock factor 1 (HSF1), is a highly conserved mechanism that induces expression of cytoprotective proteins HSP70, HSP40, and HSP27 to protect organisms against heat and other environmental stresses (Richter et al. 2010). Inhibition of HSP90 releases HSF1, resulting in in- 

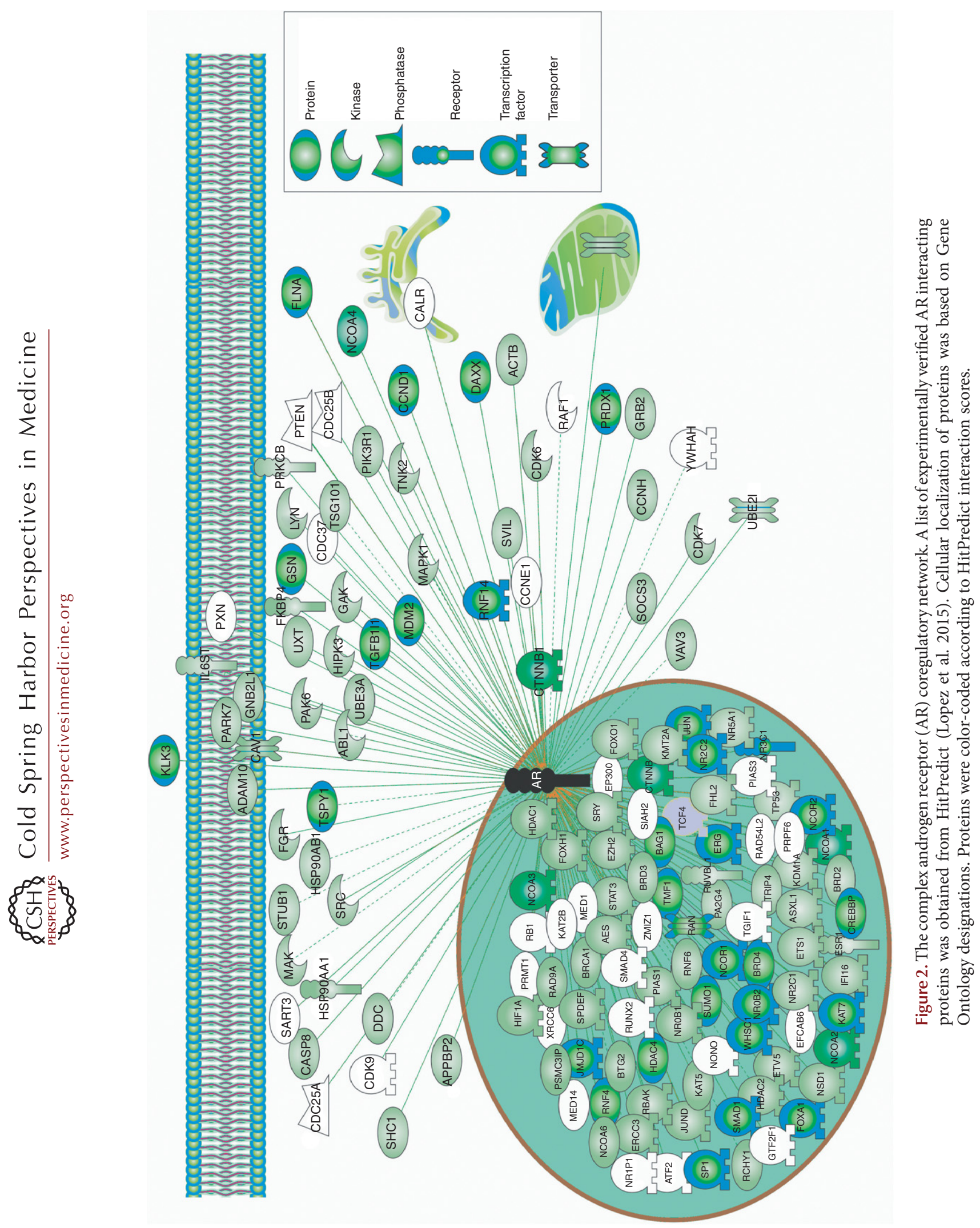
Targeting the Androgen Receptor in Prostate Cancer

creased expression of heat shock proteins that protect the cell and mediate resistance against the cytotoxicity associated with HSP90 inhibition (Bagatell et al. 2000; McCollum et al. 2006). We and others have endeavored to circumvent this issue by investigating inhibitors that target sites on HSP90 other than the amino-terminal ATP-binding pocket, such as the carboxy-terminal nucleotide binding pocket (Shelton et al. 2009; Matthews et al. 2010; Eskew et al. 2011) or the middle-linker domain (Armstrong et al. 2016). These agents show excellent antitumor activity in prostate cancer cell lines and one has shown efficacy in vivo (Eskew et al. 2011), which warrants further investigation of this class of compound to enhance their potency, solubility, and pharmacokinetic properties.

Alternative chaperones that have been investigated as potential targets for prostate cancer include HSP70, HSP27, and CLU. In addition to its role in AR maturation, HSP70 is a potent antiapoptotic factor in both normal and cancerous cells (Mosser et al. 1997). Targeting HSP70 expression with short-interfering RNA (siRNA) or antisense oligonucleotides sensitizes prostate cancer cells to apoptosis induced by a variety of cancer treatments, including ionizing radiation and taxol (Gabai et al. 2005). Despite these findings, further clinical evaluation of targeting HSP70 has been hampered by a lack of tolerable HSP70 inhibitors (Britten et al. 2000). Whereas HSP27 and CLU are not as amenable as HSP90 or HSP70 to small molecule inhibitors because they lack an ATP-binding site, antisense oligonucleotide strategies have been successfully used to achieve knockdown of these chaperones clinically. The second-generation HSP27-targeting antisense oligonucleotide OGX-427 induces proteasomal degradation of the AR, inhibits AR transcriptional activity, and results in induction of apoptosis and suppression of PSA levels and metastasis in cell line and xenograft models of prostate cancer (Kumano et al. 2012; Shiota et al. 2013; Lamoureux et al. 2014). OGX-427 has been evaluated alone and in combination with docetaxel in metastatic CRPC patients, demonstrating an acceptable safety profile and declines in PSA, measurable disease and CTC count (Hotte et al. 2012; Chi et al. 2016), and further clinical evaluation of OGX427 is ongoing. Modulation of CLU expression with siRNA or antisense oligonucleotides has also been efficacious preclinically, inhibiting both tumor growth and metastasis in xenograft models, including synergy with ionizing radiation, docetaxel and enzalutamide (Miyake et al. 2000; Gleave et al. 2001; Zellweger et al. 2002; Lamoureux et al. 2011; Matsumoto et al. 2013). On the basis of these data, the CLU antisense oligonucleotide OGX-011 entered clinical evaluation and has progressed to phase III testing (Chi et al. 2005, 2010; Saad et al. 2011) (Clinicaltrials.gov identifiers: NCT01188187; NCT01578655).

Targeting chaperone proteins for the treatment of CRPC holds significant promise but the therapeutic potential of many HSP inhibitors has been limited by their poor efficacy and/or toxicity profiles in the clinic. An alternative approach to using these agents may be in combination therapy strategies, particularly as most of the chaperone inhibitors mentioned above have shown the capacity for synergy with existing prostate cancer treatments including radiation therapy, taxanes and AR antagonists. The potential for enhanced therapeutic benefit with combinatorial treatment strategies for CRPC is discussed in greater detail later in this review.

\section{Non-LBD Targeting of the AR}

The AR-NTD is the predominant mediator of AR transcriptional activity, making it an extremely attractive therapeutic target for prostate cancer, but its intrinsic disorder and flexible structure has hindered efforts to achieve this goal. Two different types of NTD-targeting agents are currently in development. The first is the small molecule, EPI-001, which directly binds the NTD at the AF-5 activation domain (De Mol et al. 2016), thereby blocking AR/ coactivator interaction and nuclear localization to inhibit AR and ARV activity (Andersen et al. 2010; Myung et al. 2013). EPI-001 has shown promising preclinical efficacy (Andersen et al. 2010; Myung et al. 2013), although it has been 
M.M. Centenera et al.

reported to have off-target activity (Brand et al. 2015). A derivative of EPI-001, EPI-506, is currently being assessed in a phase I/II trial (Clinicaltrials.gov identifier: NCT02606123). The second type of AR-NTD targeting agent includes peptide decoys comprised of NTD sequences that competitively bind AR coactivators. A decoy peptide comprised of the entire NTD (decoy $\mathrm{AR}_{1-558}$ ) inhibits transcriptional activity of the AR under both androgen-dependent and -independent conditions in vitro and in vivo, implying that the AR-LBD is not the target of these agents (Quayle et al. 2007).

Significant homology between the DBD of the steroid receptors (Brinkmann et al. 1989) has made this region a challenge to target therapeutically. DNA-binding polyamides that bind ARE sequences to prevent AR from interacting with DNA have been developed and show inhibition of subsets of androgen-regulated genes depending on the specific sequence of the polyamide (Nickols and Dervan 2007; Chenoweth et al. 2009). For example, the sequence $5^{\prime}$ AGAACA-3' inhibits a similar number of DHT-induced transcripts as bicalutamide in prostate cancer cell lines, whereas the sequence 5'-WGWCGW-3' inhibits a significantly lower number of transcripts (Nickols and Dervan 2007). Given the diversity in sequences of AREs, mixtures of polyamides will likely be required to achieve sufficient AR inhibition with these agents for the treatment of prostate cancer. More recently, an in silico drug screen approach identified a targetable site within the AR-DBD that led to development of the morpholinyl thiazole VPC-1449, which displays potency against the AR in LNCaP cells and LNCaP xenografts similar to that of enzalutamide (Chenoweth et al. 2009; Li et al. 2014). VPC-1449 did not reduce AR levels or prevent AR nuclear localization but reduced interaction of $\mathrm{AR}$ with the PSA and TMPRSS2 gene promoters, indicating blockade of DNA binding (Dalal et al. 2014). VPC-1449 specifically inhibited AR and ARV transcriptional activity at low micromolar concentrations without cross-reactivity with GR, $\mathrm{PR}$, or ER $\alpha$ (Dalal et al. 2014), and therefore represents a potential new avenue of treatment for ARV-mediated CRPC.

\section{Genomic Interplay between Hormone Receptors}

Recent studies in breast cancer have revealed extensive interplay at the cistromic level between estrogen receptor- $\alpha(\mathrm{ER} \alpha)$, the key driver of tumor growth, and other hormone and orphan receptors (Mohammed et al. 2015; Singhal et al. 2016; Swinstead et al. 2016). Such cross talk shapes and reprograms the transcriptional activity of ER $\alpha$ to influence disease progression. For example, we recently showed that progesterone activation of the PR results in a physical association with $\mathrm{ER} \alpha$, which consequently redirects $\mathrm{ER} \alpha$ to specific sites on chromatin to induce a transcriptome that is associated with good clinical outcome. Conversely, retinoic acid receptors (Hua et al. 2009), ER- $\beta$ (Charn et al. 2010), and AR (Hu et al. 2016) can antagonize the transcriptional activity of $\mathrm{ER} \alpha$ by competing for specific chromatin binding sites: indeed, we have proposed that this is one key mechanism by which androgens suppress breast cancer growth (Hickey et al. 2012).

We predict that steroid receptor cross talk has a similar level of influence on $A R$ in the prostate. Although the functions of certain receptors, including GR, PR, ER $\alpha$, and ER $\beta$, have been investigated in prostate cancer (Arora et al. 2013), the vast majority of this work has been performed in isolation from AR. Nevertheless, two studies have shown considerable overlap ( $\sim 50 \%)$ between AR and GR chromatin binding sites in prostate cancer (Arora et al. 2013; Sahu et al. 2013), with current evidence suggesting that GR has a dual role depending on AR status: in AR-positive and androgen-responsive cells, GR can antagonize AR activity, whereas in AR-negative CRPC settings, GR could act as a "surrogate" AR to regulate an androgen-related transcriptional program and drive tumor growth (Kach et al. 2015). This finding has high clinical relevance, because corticosteroids (ligands of GR) are often used to treat patients with CRPC (Heidenreich et al. 2014). Despite these recent findings, very little is known at a molecular level about the specific mechanisms and outcomes of AR/GR cross talk and the same is true for interplay between AR and other steroid 
receptors. The challenge now is to elucidate how the chromatin interactions of these steroid receptors dictate the AR cistrome and transcriptional activity and thus prostate cancer growth and progression.

\section{Combination Strategies to Target the AR}

An improved understanding of the adaptive mechanisms used by prostate cancer cells to maintain AR signaling has underpinned the emerging paradigm that combination therapy incorporating novel and/or existing therapeutic agents may be a more effective approach to treat advanced prostate cancer. This concept is supported by mathematical modeling approaches indicating that tumor recurrences are inevitable when patients are treated sequentially with single agents, and that simultaneous administration of at least two agents is essential to achieve durable response or cure (Bozic et al. 2013). Rational combinatorial strategies with classes of agents that target different aspects of AR signaling have been the subject of many preclinical and clinical investigations. Combining existing clinical agents is particularly attractive, as extensive pharmacokinetic and pharmacodynamic data are readily available and it circumvents the need to acquire new drug licensing approvals. One successful example of this approach is the addition of the microtubule targeting chemotherapeutic docetaxel to standard ADT, which is based, in part, on the observation that docetaxel is capable of inhibiting AR expression and subcellular localization (Zhu et al. 2010; Darshan et al. 2011) and may therefore target ADT-resistant subclones of prostate tumor cells. Meta-analysis of six clinical trials evaluating chemotherapy plus ADT (termed "chemohormonal therapy") revealed improved progression-free and overall survival over ADT alone in patients with hormone-naïve metastatic prostate cancer (Ramos-Esquivel et al. 2016). This treatment regimen is now considered a valid first-line therapy for patients with metastatic, hormone-naïve prostate cancer by the National Comprehensive Cancer Network (see nccn.org/ professionals/physician_gls/pdf/prostate.pdf) and the European Society of Medical Oncology
(Parker et al. 2015). Current clinical trials investigating combinations of existing AR-targeting prostate cancer treatments are extensive and include ADT plus enzalutamide (Clinicaltrials. gov identifiers: NCT00268476, NCT02058706, NCT02677896) or abiraterone (NCT00268476, NCT01715285, NCT01786265, NCT01751451); docetaxel plus enzalutamide (NCT02288247, NCT01565928, NCT02685267, NCT02453009) or abiraterone (NCT02036060, NCT01400555); and enzalutamide plus abiraterone (NCT 01650194, NCT01949337, NCT02268175).

Strategies to combine prostate cancer treatments generally aim to maximize therapeutic efficacy while preventing cross-resistance between the drugs, thereby improving survival outcomes (van Soest et al. 2013). With this in mind, it is generally accepted that these combinations will be insufficient to prevent resistance and control progression to CRPC if they ultimately only target ligand activation of the AR. The development of combination strategies incorporating novel molecular drugs that target distinctly different aspects of the AR pathway will be critical to achieve more complete and durable suppression of AR signaling. For example, the HSP90 inhibitor AUY922, which induces AR protein degradation (Centenera et al. 2015) and inhibits AR signaling independent of AR mutations and ARVs (Gillis et al. 2013), markedly enhanced inhibition of AR signaling when used in combination with the AR antagonist bicalutamide in preclinical studies (Centenera et al. 2015). Likewise, agents that interfere with AR transcriptional activity, such as histone deacetylase inhibitors or DNA topoisomerase II inhibitors, act synergistically with AR antagonists to enhance prostate tumor cell killing in vitro and in vivo (Marrocco et al. 2007; Li et al. 2015; Carter et al. 2016).

These preclinical studies provide support for further clinical investigation, but trial design for combination therapies requires more careful consideration of patient selection, dose range and schedule, drug-drug interactions, and the potential for overlapping or unpredictable toxicities to normal tissues. To address the complexities of administering drugs simultaneously, phase I combination studies are beginning to 
M.M. Centenera et al.

use flexible and innovative designs that allow dose adjustments for maximizing target engagement, tolerability, and efficacy (Yap et al. 2013). Another important consideration is the timing of treatment, as both mathematical evidence and neoadjuvant combination trial results indicate that treating patients early in their disease course, before a sufficient number of resistant cells conferring CRPC have developed, will be key to the success of combination therapy (Bozic et al. 2013; Taplin et al. 2014).

\section{CONCLUDING REMARKS}

The importance of AR signaling through all stages of prostate cancer progression is underscored by the adaptive changes to this pathway that occur in response to androgen targeting therapy and which directly drive treatment resistance. The diversity of mechanisms prostate cancer cells deploy to maintain AR activity creates a major clinical challenge. Improving our understanding of these AR resistance mechanisms, and translating them into the next generation of AR targeting agents, will be key to improving the health and well-being of men with prostate cancer.

\section{ACKNOWLEDGMENTS}

M.M.C. was supported by a Young Investigator Award from the Prostate Cancer Foundation of Australia (YIG0412); L.A.S. was supported by a Young Investigator Award from the Prostate Cancer Foundation (the Foundation 14 award); L.M.B. is supported by a Future Fellowship from the Australian Research Council (FT130101004). W.D.T. acknowledges grant support from the U.S. Department of Defense Prostate Cancer Research Program Transformative Impact Award (ID W81XWH-13-2-0093). L.A.S. and W.D.T. acknowledge grant support from the National Health and Medical Research Council (Grant ID 1083961). M.M.C., L.A.S., L.M.B., and W.D.T. acknowledge grant support from Cancer Australia/PCFA (ID 1050880, 1085471, 1012337 and 1043482). All authors acknowledge grant support from the Movember
Foundation/Prostate Cancer Foundation of Australia (MRTA 3).

\section{REFERENCES}

Andersen RJ, Mawji NR, Wang J, Wang G, Haile S, Myung JK, Watt K, Tam T, Yang YC, Banuelos CA, et al. 2010. Regression of castrate-recurrent prostate cancer by a small-molecule inhibitor of the amino-terminus domain of the androgen receptor. Cancer Cell 17: 535-546.

Antonarakis ES, Lu C, Luber B, Wang H, Chen Y, Nakazawa M, Nadal R, Paller CJ, Denmeade SR, Carducci MA, et al. 2015. Androgen receptor splice variant 7 and efficacy of taxane chemotherapy in patients with metastatic castration-resistant prostate cancer. JAMA Oncol 1: 582-591.

Antonarakis ES, Lu C, Wang H, Luber B, Nakazawa M, Roeser JC, Chen Y, Mohammad TA, Chen Y, Fedor HL, et al. 2014. AR-V7 and resistance to enzalutamide and abiraterone in prostate cancer. N Engl J Med 371: 10281038.

Armstrong HK, Koay YC, Irani S, Das R, Nassar ZD, The Australian Prostate Cancer B, Selth LA, Centenera MM, McAlpine SR, Butler LM. 2016. A novel class of Hsp90 Cterminal modulators have pre-clinical efficacy in prostate tumor cells without induction of a heat shock response. Prostate 76: 1546-1559.

Arora VK, Schenkein E, Murali R, Subudhi SK, Wongvipat J, Balbas MD, Shah N, Cai L, Efstathiou E, Logothetis C, et al. 2013. Glucocorticoid receptor confers resistance to antiandrogens by bypassing androgen receptor blockade. Cell 155: 1309-1322.

Asim M, Massie CE, Orafidiya F, Pertega-Gomes N, Warren AY, Esmaeili M, Selth LA, Zecchini HI, Luko K, Qureshi A, et al. 2016. Choline kinase $\alpha$ as an androgen receptor chaperone and prostate cancer therapeutic target. J Natl Cancer Inst $\mathbf{1 0 8 .}$

Attard G, Belldegrun AS, de Bono JS. 2005. Selective blockade of androgenic steroid synthesis by novel lyase inhibitors as a therapeutic strategy for treating metastatic prostate cancer. BJU Int 96: 1241-1246.

Attard G, Parker C, Eeles RA, Schroder F, Tomlins SA, Tannock I, Drake CG, de Bono JS. 2016. Prostate cancer. Lancet 387: 70-82.

Azad AA, Volik SV, Wyatt AW, Haegert A, Le Bihan S, Bell RH, Anderson SA, McConeghy B, Shukin R, Bazov J, et al. 2015a. Androgen receptor gene aberrations in circulating cell-free DNA: Biomarkers of therapeutic resistance in castration-resistant prostate cancer. Clin Cancer Res 21: 2315-2324.

Azad AA, Zoubeidi A, Gleave ME, Chi KN. 2015b. Targeting heat shock proteins in metastatic castration-resistant prostate cancer. Nat Rev Urol 12: 26-36.

Bagatell R, Paine-Murrieta GD, Taylor CW, Pulcini EJ, Akinaga S, Benjamin IJ, Whitesell L. 2000. Induction of a heat shock factor 1-dependent stress response alters the cytotoxic activity of hsp90-binding agents. Clin Cancer Res 6: 3312-3318.

Barbieri CE, Baca SC, Lawrence MS, Demichelis F, Blattner M, Theurillat JP, White TA, Stojanov P, Van Allen E, Stransky N, et al. 2012. Exome sequencing identifies re- 
current SPOP, FOXA1 and MED12 mutations in prostate cancer. Nat Genet 44: 685-689.

Berrevoets CA, Doesburg P, Steketee K, Trapman J, Brinkmann AO. 1998. Functional interactions of the AF-2 activation domain core region of the human androgen receptor with the amino-terminal domain and with the transcriptional coactivator TIF2 (transcriptional intermediary factor2). Mol Endocrinol 12: 1172-1183.

Biron E, Bedard F. 2015. Recent progress in the development of protein-protein interaction inhibitors targeting androgen receptor-coactivator binding in prostate cancer. J Steroid Biochem Mol Biol 161: 36-44.

Bolton EC, So AY, Chaivorapol C, Haqq CM, Li H, Yamamoto KR. 2007. Cell- and gene-specific regulation of primary target genes by the androgen receptor. Genes Dev 21: 2005-2017.

Bozic I, Reiter JG, Allen B, Antal T, Chatterjee K, Shah P, Moon YS, Yaqubie A, Kelly N, Le DT, et al. 2013. Evolutionary dynamics of cancer in response to targeted combination therapy. eLife 2: e00747.

Brand LJ, Olson ME, Ravindranathan P, Guo H, Kempema AM, Andrews TE, Chen X, Raj GV, Harki DA, Dehm SM. 2015. EPI-001 is a selective peroxisome proliferatoractivated receptor- $\gamma$ modulator with inhibitory effects on androgen receptor expression and activity in prostate cancer. Oncotarget 6: 3811-3824.

Brinkmann AO, Faber PW, van Rooij HC, Kuiper GG, Ris C, Klaassen P, van der Korput JA, Voorhorst MM, van Laar JH, Mulder E, et al. 1989. The human androgen receptor: Domain structure, genomic organization and regulation of expression. J Steroid Biochem 34: 307-310.

Britten CD, Rowinsky EK, Baker SD, Weiss GR, Smith L, Stephenson J, Rothenberg M, Smetzer L, Cramer J, Collins W, et al. 2000. A phase I and pharmacokinetic study of the mitochondrial-specific rhodacyanine dye analog MKT 077. Clin Cancer Res 6: 42-49.

Brodie J, McEwan IJ. 2005. Intra-domain communication between the N-terminal and DNA-binding domains of the androgen receptor: Modulation of androgen response element DNA binding. J Mol Endocrinol 34: 603-615.

Bubendorf L, Kononen J, Koivisto P, Schraml P, Moch H, Gasser TC, Willi N, Mihatsch MJ, Sauter G, Kallioniemi OP. 1999. Survey of gene amplifications during prostate cancer progression by high-throughout fluorescence in situ hybridization on tissue microarrays. Cancer Res 59: 803-806.

Buchanan G, Greenberg NM, Scher HI, Harris JM, Marshall VR, Tilley WD. 2001. Collocation of androgen receptor gene mutations in prostate cancer. Clin Cancer Res 7: 1273-1281.

Buchanan G, Ricciardelli C, Harris JM, Prescott J, Yu ZC, Jia L, Butler LM, Marshall VR, Scher HI, Gerald WL, et al. 2007. Control of androgen receptor signaling in prostate cancer by the cochaperone small glutamine rich tetratricopeptide repeat containing protein $\alpha$. Cancer Res 67: 10087-10096.

Butler LM, Ferraldeschi R, Armstrong HK, Centenera MM, Workman P. 2015. Maximizing the therapeutic potential of HSP90 inhibitors. Mol Cancer Res 13: 1445-1451.

Carreira S, Romanel A, Goodall J, Grist E, Ferraldeschi R, Miranda S, Prandi D, Lorente D, Frenel JS, Pezaro C, et al.
2014. Tumor clone dynamics in lethal prostate cancer. Sci Transl Med 6: 254ra125.

Carrello A, Ingley E, Minchin RF, Tsai S, Ratajczak T. 1999. The common tetratricopeptide repeat acceptor site for steroid receptor-associated immunophilins and hop is located in the dimerization domain of Hsp90. J Biol Chem 274: 2682-2689.

Carter SL, Centenera MM, Tilley WD, Selth LA, Butler LM. 2016. I $\kappa \mathrm{B} \alpha$ mediates prostate cancer cell death induced by combinatorial targeting of the androgen receptor. $B M C$ Cancer 16: 141.

Centenera MM, Carter SL, Gillis JL, Marrocco-Tallarigo DL, Grose RH, Tilley WD, Butler LM. 2015. Co-targeting AR and HSP90 suppresses prostate cancer cell growth and prevents resistance mechanisms. Endocr Relat Cancer 22: $805-818$.

Centenera MM, Gillis JL, Hanson A, Jindal S, Taylor RA, Risbridger G, Sutherland PD, Scher HI, Raj GV, Knudsen $\mathrm{KE}$, et al. 2012. Evidence for efficacy of new Hsp90 inhibitors revealed by ex vivo culture of human prostate tumors. Clin Cancer Res 18: 3562-3570.

Chan SC, Dehm SM. 2014. Constitutive activity of the androgen receptor. Adv Pharmacol 70: 327-366.

Chan SC, Selth LA, Li Y, Nyquist MD, Miao L, Bradner JE, Raj GV, Tilley WD, Dehm SM. 2015. Targeting chromatin binding regulation of constitutively active AR variants to overcome prostate cancer resistance to endocrinebased therapies. Nucleic Acids Res 43: 5880-5897.

Charn TH, Liu ET, Chang EC, Lee YK, Katzenellenbogen JA, Katzenellenbogen BS. 2010. Genome-wide dynamics of chromatin binding of estrogen receptors $\alpha$ and $\beta$ : Mutual restriction and competitive site selection. Mol Endocrinol 24: 47-59.

Chen CD, Welsbie DS, Tran C, Baek SH, Chen R, Vessella R, Rosenfeld MG, Sawyers CL. 2004. Molecular determinants of resistance to antiandrogen therapy. Nat Med 10: 33-39.

Chen S, Smith DF. 1998. Hop as an adaptor in the heat shock protein 70 (Hsp70) and hsp90 chaperone machinery. J Biol Chem 273: 35194-35200.

Chen S, Sullivan WP, Toft DO, Smith DF. 1998. Differential interactions of $\mathrm{p} 23$ and the TPR-containing proteins Hop, Cyp40, FKBP52 and FKBP51 with Hsp90 mutants. Cell Stress Chaperones 3: 118-129.

Chenoweth DM, Harki DA, Phillips JW, Dose C, Dervan PB. 2009. Cyclic pyrrole-imidazole polyamides targeted to the androgen response element. J Am Chem Soc 131: 7182-7188.

Chi KN, Eisenhauer E, Fazli L, Jones EC, Goldenberg SL, Powers J, Tu D, Gleave ME. 2005. A phase I pharmacokinetic and pharmacodynamic study of OGX-011, a $2^{\prime}$ methoxyethyl antisense oligonucleotide to clusterin, in patients with localized prostate cancer. J Natl Cancer Inst 97: 1287-1296.

Chi KN, Hotte SJ, Yu EY, Tu D, Eigl BJ, Tannock I, Saad F, North S, Powers J, Gleave ME, et al. 2010. Randomized phase II study of docetaxel and prednisone with or without OGX-011 in patients with metastatic castration-resistant prostate cancer. J Clin Oncol 28: 4247-4254.

Chi KN, Yu EY, Jacobs C, Bazov J, Kollmannsberger C, Higano CS, Mukherjee SD, Gleave ME, Stewart PS, Hotte SJ. 2016. A phase I dose-escalation study of apatorsen 
M.M. Centenera et al.

(OGX-427), an antisense inhibitor targeting heat shock protein 27 (Hsp27), in patients with castration-resistant prostate cancer and other advanced cancers. Ann Oncol 27: 1116-1122.

Chmelar R, Buchanan G, Need EF, Tilley W, Greenberg NM. 2007. Androgen receptor coregulators and their involvement in the development and progression of prostate cancer. Int J Cancer 120: 719-733.

Claessens F, Alen P, Devos A, Peeters B, Verhoeven G, Rombauts W. 1996. The androgen-specific probasin response element 2 interacts differentially with androgen and glucocorticoid receptors. J Biol Chem 271: 19013-19016.

Claessens F, Gewirth DT. 2004. DNA recognition by nuclear receptors. Essays Biochem 40: 59-72.

Claessens F, Verrijdt G, Schoenmakers E, Haelens A, Peeters B, Verhoeven G, Rombauts W. 2001. Selective DNA binding by the androgen receptor as a mechanism for hormone-specific gene regulation. J Steroid Biochem Mol Biol 76: $23-30$.

Clegg NJ, Wongvipat J, Joseph JD, Tran C, Ouk S, Dilhas A, Chen Y, Grillot K, Bischoff ED, Cai L, et al. 2012. ARN509: A novel antiandrogen for prostate cancer treatment. Cancer Res 72: 1494-1503.

Clinckemalie L, Vanderschueren D, Boonen S, Claessens F. 2012. The hinge region in androgen receptor control. Mol Cell Endocrinol 358: 1-8.

Culig Z, Hoffmann J, Erdel M, Eder IE, Hobisch A, Hittmair A, Bartsch G, Utermann G, Schneider MR, Parczyk $\mathrm{K}$, et al. 1999. Switch from antagonist to agonist of the androgen receptor bicalutamide is associated with prostate tumour progression in a new model system. $\mathrm{Br} \mathrm{J}$ Cancer 81: 242-251.

Cutress ML, Whitaker HC, Mills IG, Stewart M, Neal DE. 2008. Structural basis for the nuclear import of the human androgen receptor. J Cell Sci 121: 957-968.

Dalal K, Roshan-Moniri M, Sharma A, Li H, Ban F, Hassona MD, Hsing M, Singh K, LeBlanc E, Dehm S, et al. 2014. Selectively targeting the DNA-binding domain of the androgen receptor as a prospective therapy for prostate cancer. J Biol Chem 289: 26417-26429.

Danielian PS, White R, Lees JA, Parker MG. 1992. Identification of a conserved region required for hormone dependent transcriptional activation by steroid hormone receptors. EMBO J 11: 1025-1033.

Darshan MS, Loftus MS, Thadani-Mulero M, Levy BP, Escuin D, Zhou XK, Gjyrezi A, Chanel-Vos C, Shen R, Tagawa ST, et al. 2011. Taxane-induced blockade to nuclear accumulation of the androgen receptor predicts clinical responses in metastatic prostate cancer. Cancer Res 71: 6019-6029.

de Bono JS, Logothetis CJ, Molina A, Fizazi K, North S, Chu L, Chi KN, Jones RJ, Goodman OB Jr, Saad F, et al. 2011. Abiraterone and increased survival in metastatic prostate cancer. N Engl J Med 364: 1995-2005.

De Mol E, Fenwick RB, Phang CT, Buzon V, Szulc E, de la Fuente A, Escobedo A, Garcia J, Bertoncini CW, Estebanez-Perpina E, et al. 2016. EPI-001, a compound active against castration-resistant prostate cancer, targets transactivation unit 5 of the androgen receptor. ACS Chem Biol 11: 2499-2505.

DePriest AD, Fiandalo MV, Schlanger S, Heemers F, Mohler JL, Liu S, Heemers HV. 2016. Regulators of androgen action resource: A one-stop shop for the comprehensive study of androgen receptor action. Database (Oxford) 2016.

Dittmar KD, Demady DR, Stancato LF, Krishna P, Pratt WB. 1997. Folding of the glucocorticoid receptor by the heat shock protein (hsp) 90-based chaperone machinery. The role of p23 is to stabilize receptor.hsp90 heterocomplexes formed by hsp90.p60.hsp70. J Biol Chem 272: 2121321220.

Efstathiou E, Titus M, Wen S, Hoang A, Karlou M, Ashe R, Tu SM, Aparicio A, Troncoso P, Mohler J, et al. 2015. Molecular characterization of enzalutamide-treated bone metastatic castration-resistant prostate cancer. Eur Urol 67: 53-60.

Eskew JD, Sadikot T, Morales P, Duren A, Dunwiddie I, Swink M, Zhang X, Hembruff S, Donnelly A, Rajewski RA, et al. 2011. Development and characterization of a novel C-terminal inhibitor of Hsp90 in androgen dependent and independent prostate cancer cells. BMC Cancer 11: 468.

Evans RM. 1988. The steroid and thyroid hormone receptor superfamily. Science 240: 889-895.

Fan CY, Lee S, Cyr DM. 2003. Mechanisms for regulation of Hsp70 function by Hsp40. Cell Stress Chaperones 8: 309-316.

Fang Y, Fliss AE, Robins DM, Caplan AJ. 1996. Hsp90 regulates androgen receptor hormone binding affinity in vivo. J Biol Chem 271: 28697-28702.

Fleuren EDG, Zhang L, Wu J, Daly RJ. 2016. The kinome 'at large' in cancer. Nat Rev Cancer 16: 83-98.

Foley C, Mitsiades N. 2016. Moving beyond the androgen receptor (AR): Targeting AR-interacting proteins to treat prostate cancer. Hormones Cancer 7: 84-103.

Gabai VL, Budagova KR, Sherman MY. 2005. Increased expression of the major heat shock protein Hsp72 in human prostate carcinoma cells is dispensable for their viability but confers resistance to a variety of anticancer agents. Oncogene 24: 3328-3338.

Galigniana MD, Erlejman AG, Monte M, Gomez-Sanchez C, Piwien-Pilipuk G. 2010. The hsp90-FKBP52 complex links the mineralocorticoid receptor to motor proteins and persists bound to the receptor in early nuclear events. Mol Cell Biol 30: 1285-1298.

Galigniana MD, Harrell JM, Murphy PJ, Chinkers M, Radanyi C, Renoir JM, Zhang M, Pratt WB. 2002. Binding of hsp90-associated immunophilins to cytoplasmic dynein: Direct binding and in vivo evidence that the peptidylprolyl isomerase domain is a dynein interaction domain. Biochem 41: 13602-13610.

Germain P, Staels B, Dacquet C, Spedding M, Laudet V. 2006. Overview of nomenclature of nuclear receptors. Pharmacol Rev 58: 685-704.

Gillis JL, Selth LA, Centenera MM, Townley SL, Sun S, Plymate SR, Tilley WD, Butler LM. 2013. Constitutively active androgen receptor variants function independently of the HSP90 chaperone but do not confer resistance to HSP90 inhibitors. Oncotarget 4: 691-704.

Glass CK, Rosenfeld MG. 2000. The coregulator exchange in transcriptional functions of nuclear receptors. Genes Dev 14: $121-141$. 
Gleave ME, Miyake H, Zellweger T, Chi K, July L, Nelson C, Rennie P. 2001. Use of antisense oligonucleotides targeting the antiapoptotic gene, clusterin/testosterone-repressed prostate message 2, to enhance androgen sensitivity and chemosensitivity in prostate cancer. Urology 58 : $39-49$.

Gottlieb B, Beitel LK, Wu JH, Trifiro M. 2004. The androgen receptor gene mutations database (ARDB): 2004 update. Hum Mutat 23: 527-533.

Grasso CS, Wu YM, Robinson DR, Cao X, Dhanasekaran SM, Khan AP, Quist MJ, Jing X, Lonigro RJ, Brenner JC, et al. 2012. The mutational landscape of lethal castration-resistant prostate cancer. Nature 487: 239-243.

Grenert JP, Johnson BD, Toft DO. 1999. The importance of ATP binding and hydrolysis by hsp90 in formation and function of protein heterocomplexes. J Biol Chem 274: 17525-17533.

Gundem G, Van Loo P, Kremeyer B, Alexandrov LB, Tubio JM, Papaemmanuil E, Brewer DS, Kallio HM, Hognas G, Annala M, et al. 2015. The evolutionary history of lethal metastatic prostate cancer. Nature 520: 353-357.

Harrell JM, Kurek I, Breiman A, Radanyi C, Renoir JM, Pratt WB, Galigniana MD. 2002. All of the protein interactions that link steroid receptor.hsp90.immunophilin heterocomplexes to cytoplasmic dynein are common to plant and animal cells. Biochemistry 41: 5581-5587.

He B, Gampe RT Jr, Kole AJ, Hnat AT, Stanley TB, An G Stewart EL, Kalman RI, Minges JT, Wilson EM. 2004. Structural basis for androgen receptor interdomain and coactivator interactions suggests a transition in nuclear receptor activation function dominance. Mol Cell 16: 425-438.

He B, Kemppainen JA, Wilson EM. 2000. FXXLF and WXXLF sequences mediate the $\mathrm{NH} 2$-terminal interaction with the ligand binding domain of the androgen receptor. J Biol Chem 275: 22986-22994.

He B, Minges JT, Lee LW, Wilson EM. 2002. The FXXLF motif mediates androgen receptor-specific interactions with coregulators. J Biol Chem 277: 10226-10235.

He B, Wilson EM. 2002. The $\mathrm{NH}_{2}$-terminal and carboxylterminal interaction in the human androgen receptor. Mol Genet Metab 75: 293-298.

Heemers HV, Tindall DJ. 2007. Androgen receptor (AR) coregulators: A diversity of functions converging on and regulating the AR transcriptional complex. Endocr Rev 28: 778-808.

Heery DM, Kalkhoven E, Hoare S, Parker MG. 1997. A signature motif in transcriptional co-activators mediates binding to nuclear receptors. Nature 387: 733-736.

Heidenreich A, Bastian PJ, Bellmunt J, Bolla M, Joniau S, van der Kwast T, Mason M, Matveev V, Wiegel T, Zattoni F, et al. 2014. EAU guidelines on prostate cancer. Part II: Treatment of advanced, relapsing, and castration-resistant prostate cancer. Eur Urol 65: 467-479.

Henzler C, Li Y, Yang R, McBride T, Ho Y, Sprenger C, Liu G, Coleman I, Lakely B, Li R, et al. 2016. Truncation and constitutive activation of the androgen receptor by diverse genomic rearrangements in prostate cancer. Nat Comm 7: 13668.

Hernandez MP, Sullivan WP, Toft DO. 2002. The assembly and intermolecular properties of the hsp70-Hop-hsp90 molecular chaperone complex. J Biol Chem 277: 3829438304 .

Hickey TE, Robinson JL, Carroll JS, Tilley WD. 2012. Minireview: The androgen receptor in breast tissues: Growth inhibitor, tumor suppressor, oncogene? Mol Endocrinol 26: 1252-1267.

Hornberg E, Ylitalo EB, Crnalic S, Antti H, Stattin P, Widmark A, Bergh A, Wikstrom P. 2011. Expression of androgen receptor splice variants in prostate cancer bone metastases is associated with castration-resistance and short survival. PLoS ONE 6: e19059.

Hotte SJ, Yu EY, Hirte HW, Higano CS, Gleave M, Chi K. 2012. Phase I trial of OGX-427, a 2'methoxyethyl antisense oligonucleotide (ASO), against heat shock protein 27 (Hsp27): Final results. J Clin Oncol, 2010 ASCO Annual Meeting Proceedings 28: 2077.

Hu DG, Selth L, Tarulli G, Meech R, Chanawong A, Wijayakumara D, Russell R, Caldas C, Robinson JLL, Carroll J, et al. 2016. Androgen and estrogen receptors in breast cancer co-regulate human UDP-glucuronosyltransferases 2B15 and 2B17. Cancer Res 76: 5881-5893.

Hua S, Kittler R, White KP. 2009. Genomic antagonism between retinoic acid and estrogen signaling in breast cancer. Cell 137: 1259-1271.

Huggins C, Stephens RC, Hodges CV. 1941. Studies on prostatic cancer: The effects of castration on advanced carcinoma of the prostate gland. Arch Surgery 43: 209.

Ikonen T, Palvimo JJ, Janne OA. 1997. Interaction between the amino- and carboxyl-terminal regions of the rat androgen receptor modulates transcriptional activity and is influenced by nuclear receptor coactivators. J Biol Chem 272: 29821-29828.

Janin YL. 2010. ATPase inhibitors of heat-shock protein 90 , second season. Drug Discov Today 15: 342-353.

Jenster G, van der Korput HA, Trapman J, Brinkmann AO. 1995. Identification of two transcription activation units in the N-terminal domain of the human androgen receptor. J Biol Chem 270: 7341-7346.

Kach J, Conzen SD, Szmulewitz RZ. 2015. Targeting the glucocorticoid receptor in breast and prostate cancers. Sci Transl Med 7: 305ps319.

Karantanos T, Evans CP, Tombal B, Thompson TC, Montironi R, Isaacs WB. 2015. Understanding the mechanisms of androgen deprivation resistance in prostate cancer at the molecular level. Eur Urol 67: 470-479.

Knudsen KE, Scher HI. 2009. Starving the addiction: New opportunities for durable suppression of AR signaling in prostate cancer. Clin Cancer Res 15: 4792-4798.

Koivisto P, Kononen J, Palmberg C, Tammela T, Hyytinen E, Isola J, Trapman J, Cleutjens K, Noordzij A, Visakorpi T, et al. 1997. Androgen receptor gene amplification: A possible molecular mechanism for androgen deprivation therapy failure in prostate cancer. Cancer Res 57: 314319.

Kumano M, Furukawa J, Shiota M, Zardan A, Zhang F, Beraldi E, Wiedmann RM, Fazli L, Zoubeidi A, Gleave ME. 2012. Cotargeting stress-activated Hsp27 and autophagy as a combinatorial strategy to amplify endoplasmic reticular stress in prostate cancer. Mol Cancer Therapeut 11: 1661-1671. 
M.M. Centenera et al.

Kumar R, Betney R, Li J, Thompson EB, McEwan IJ. 2004 Induced $\alpha$-helix structure in AF1 of the androgen receptor upon binding transcription factor TFIIF. Biochemistry 43: 3008-3013.

Labrie F. 2011. Blockade of testicular and adrenal androgens in prostate cancer treatment. Nat Rev Urol 8: 73-85.

Lack NA, Axerio-Cilies P, Tavassoli P, Han FQ, Chan KH, Feau C, LeBlanc E, Guns ET, Guy RK, Rennie PS, et al. 2011. Targeting the binding function 3 (BF3) site of the human androgen receptor through virtual screening. J Med Chem 54: 8563-8573.

Lallous N, Volik SV, Awrey S, Leblanc E, Tse R, Murillo J, Singh K, Azad AA, Wyatt AW, LeBihan S, et al. 2016. Functional analysis of androgen receptor mutations that confer anti-androgen resistance identified in circulating cell-free DNA from prostate cancer patients. Genome Biol 17: 10 .

Lamoureux F, Thomas C, Yin MJ, Fazli L, Zoubeidi A, Gleave ME. 2014. Suppression of heat shock protein 27 using OGX-427 induces endoplasmic reticulum stress and potentiates heat shock protein 90 inhibitors to delay castrate-resistant prostate cancer. Eur Urol 66: 145-155.

Lamoureux F, Thomas C, Yin MJ, Kuruma H, Beraldi E, Fazli L, Zoubeidi A, Gleave ME. 2011. Clusterin inhibition using OGX-011 synergistically enhances Hsp90 inhibitor activity by suppressing the heat shock response in castrate-resistant prostate cancer. Cancer Res 71: 5838-5849.

Langley E, Kemppainen JA, Wilson EM. 1998. Intermolecular $\mathrm{NH}_{2}$-/carboxyl-terminal interactions in androgen receptor dimerization revealed by mutations that cause androgen insensitivity. J Biol Chem 273: 92-101.

Luo J, Attard G, Balk SP, Bevan C, Burnstein K, Cato L, Cherkasov A, De Bono JS, Dong Y, Gao AC, et al. 2017. Role of androgen receptor variants in prostate cancer: Report from the 2017 Mission Androgen Receptor Variants Meeting. Eur Urol doi: 10.1016/j.eururo.2017.11.038.

Li H, Ban F, Dalal K, Leblanc E, Frewin K, Ma D, Adomat H, Rennie PS, Cherkasov A. 2014. Discovery of small-molecule inhibitors selectively targeting the DNA-binding domain of the human androgen receptor. J Med Chem 57: 6458-6467.

Li H, Wang Z, Tang K, Zhou H, Liu H, Yan L, Guan W, Chen K, Xu H, Ye Z. 2017. Prognostic value of androgen receptor splice variant 7 in the treatment of castration-resistant prostate cancer with next generation androgen receptor signal inhibition: A systematic review and meta-analysis. Eur Urol Focus doi: 10.1016/j.euf.2017.01.004.

Li H, Xie N, Gleave ME, Dong X. 2015. Catalytic inhibitors of DNA topoisomerase II suppress the androgen receptor signaling and prostate cancer progression. Oncotarget 6: 20474-20484.

Linja MJ, Savinainen KJ, Saramaki OR, Tammela TL, Vessella RL, Visakorpi T. 2001. Amplification and overexpression of androgen receptor gene in hormone-refractory prostate cancer. Cancer Res 61: 3550-3555.

Lopez Y, Nakai K, Patil A. 2015. HitPredict version 4: Comprehensive reliability scoring of physical protein-protein interactions from more than 100 species. Database (Oxford) 2015: bav117.

Lu NZ, Wardell SE, Burnstein KL, Defranco D, Fuller PJ, Giguere V, Hochberg RB, McKay L, Renoir JM, Weigel NL, et al. 2006. International Union of Pharmacology.
LXV. The pharmacology and classification of the nuclear receptor superfamily: Glucocorticoid, mineralocorticoid, progesterone, and androgen receptors. Pharmacol Rev 58: 782-797.

Lubahn DB, Joseph DR, Sullivan PM, Willard HF, French FS, Wilson EM. 1988. Cloning of human androgen receptor complementary DNA and localization to the X chromosome. Science 240: 327-330.

Luisi BF, Xu WX, Otwinowski Z, Freedman LP, Yamamoto KR, Sigler PB. 1991. Crystallographic analysis of the interaction of the glucocorticoid receptor with DNA. Nature 352: 497-505.

Lupien M, Brown M. 2009. Cistromics of hormone-dependent cancer. Endocr Relat Cancer 16: 381-389.

Markowski MC, Frick KD, Eshleman JR, Luo J, Antonarakis ES. 2016. Cost-savings analysis of AR-V7 testing in patients with metastatic castration-resistant prostate cancer eligible for treatment with abiraterone or enzalutamide. Prostate 76: 1484-1490.

Marrocco DL, Tilley WD, Bianco-Miotto T, Evdokiou A Scher HI, Rifkind RA, Marcs PA, Richon VM, Butler LM. 2007. Suberoylanilide hydoxamic acid (SAHA; vorinostat) represses androgen receptor expression and acts synergistically with an androgen receptor antagonist to inhibit prostate cancer cell proliferation. Mol Cancer Therapeut 6: 51-60.

Massie CE, Adryan B, Barbosa-Morais NL, Lynch AG, Tran MG, Neal DE, Mills IG. 2007. New androgen receptor genomic targets show an interaction with the ETS1 transcription factor. EMBO Rep 8: 871-878.

Matias PM, Donner P, Coelho R, Thomaz M, Peixoto C, Macedo S, Otto N, Joschko S, Scholz P, Wegg A, et al. 2000. Structural evidence for ligand specificity in the binding domain of the human androgen receptor. Implications for pathogenic gene mutations. J Biol Chem 275: 26164-26171.

Matsumoto H, Yamamoto Y, Shiota M, Kuruma H, Beraldi E, Matsuyama H, Zoubeidi A, Gleave M. 2013. Cotargeting androgen receptor and clusterin delays castrate-resistant prostate cancer progression by inhibiting adaptive stress response and AR stability. Cancer Res 73: 5206 5217.

Matthews SB, Vielhauer GA, Manthe CA, Chaguturu VK, Szabla K, Matts RL, Donnelly AC, Blagg BS, Holzbeierlein JM. 2010. Characterization of a novel novobiocin analogue as a putative C-terminal inhibitor of heat shock protein 90 in prostate cancer cells. Prostate 70: 27-36.

McCollum AK, Teneyck CJ, Sauer BM, Toft DO, Erlichman C. 2006. Up-regulation of heat shock protein 27 induces resistance to 17-allylamino-demethoxygeldanamycin through a glutathione-mediated mechanism. Cancer Res 66: 10967-10975.

McEwan IJ, Gustafsson J. 1997. Interaction of the human androgen receptor transactivation function with the general transcription factor TFIIF. Proc Natl Acad Sci 94: 8485-8490.

McPhaul MJ, Marcelli M, Tilley WD, Griffin JE, Wilson JD. 1991. Androgen resistance caused by mutations in the androgen receptor gene. FASEB J 5: 2910-2915.

Miyake H, Chi KN, Gleave ME. 2000. Antisense TRPM-2 oligodeoxynucleotides chemosensitize human androgen- 
independent PC-3 prostate cancer cells both in vitro and in vivo. Clin Cancer Res 6: 1655-1663.

Mohammed H, Russell IA, Stark R, Rueda OM, Hickey TE, Tarulli GA, Serandour AA, Birrell SN, Bruna A, Saadi A, et al. 2015. Progesterone receptor modulates ER $\alpha$ action in breast cancer. Nature 523: 313-317.

Mohammed H, Taylor C, Brown GD, Papachristou EK, Carroll JS, D'Santos CS. 2016. Rapid immunoprecipitation mass spectrometry of endogenous proteins (RIME) for analysis of chromatin complexes. Nat Protoc 11: 316-326.

Morishima Y, Kanelakis KC, Murphy PJ, Lowe ER, Jenkins GJ, Osawa Y, Sunahara RK, Pratt WB. 2003. The hsp90 cochaperone p23 is the limiting component of the multiprotein hsp90/hsp70-based chaperone system in vivo where it acts to stabilize the client protein: $\mathrm{Hsp} 90$ complex. J Biol Chem 278: 48754-48763.

Mosser DD, Caron AW, Bourget L, Denis-Larose C, Massie B. 1997. Role of the human heat shock protein hsp70 in protection against stress-induced apoptosis. Mol Cell Biol 17: 5317-5327.

Munuganti RS, Leblanc E, Axerio-Cilies P, Labriere C, Frewin K, Singh K, Hassona MD, Lack NA, Li H, Ban F, et al. 2013. Targeting the binding function 3 (BF3) site of the androgen receptor through virtual screening. 2 . Development of 2-((2-phenoxyethyl) thio)-1H-benzimidazole derivatives. J Med Chem 56: 1136-1148.

Myung JK, Banuelos CA, Fernandez JG, Mawji NR, Wang J, Tien AH, Yang YC, Tavakoli I, Haile S, Watt K, et al. 2013. An androgen receptor $\mathrm{N}$-terminal domain antagonist for treating prostate cancer. J Clin Invest 123: 2948-2960.

Ni L, Yang CS, Gioeli D, Frierson H, Toft DO, Paschal BM. 2010. FKBP51 promotes assembly of the Hsp90 chaperone complex and regulates androgen receptor signaling in prostate cancer cells. Mol Cell Biol 30: 1243-1253.

Nickols NG, Dervan PB. 2007. Suppression of androgen receptor-mediated gene expression by a sequence-specific DNA-binding polyamide. Proc Natl Acad Sci 104: 1041810423.

O’Donnell A, Judson I, Dowsett M, Raynaud F, Dearnaley D, Mason M, Harland S, Robbins A, Halbert G, Nutley B, et al. 2004. Hormonal impact of the $17 \alpha$-hydroxylase $/ \mathrm{C}_{17,20^{-}}$ lyase inhibitor abiraterone acetate (CB7630) in patients with prostate cancer. Br J Cancer 90: 2317-2325.

Onstenk W, Sieuwerts AM, Kraan J, Van M, Nieuweboer AJ, Mathijssen RH, Hamberg P, Meulenbeld HJ, De Laere B, Dirix LY, et al. 2015. Efficacy of cabazitaxel in castrationresistant prostate cancer is independent of the presence of AR-V7 in circulating tumor cells. Eur Urol 68: 939-945.

Paltoglou S, Das R, Townley SL, Hickey TE, Tarulli GA Coutinho I, Fernandes R, Hanson AR, Denis I, Carroll JS, et al. 2017. Novel androgen receptor coregulator GRHL2 exerts both oncogenic and antimetastatic functions in prostate cancer. Cancer Res 77: 3417-3430.

Parker C, Gillessen S, Heidenreich A, Horwich A, Committee EG. 2015. Cancer of the prostate: ESMO Clinical Practice Guidelines for diagnosis, treatment and follow-up. Ann Oncol 26: v69-77.

Potter GA, Barrie SE, Jarman M, Rowlands MG. 1995. Novel steroidal inhibitors of human cytochrome P45017 $\alpha$ (17 $\alpha$-hydroxylase-C17,20-lyase): Potential agents for the treatment of prostatic cancer. J Med Chem 38: 2463-2471.
Pratt WB, Toft DO. 1997. Steroid receptor interactions with heat shock protein and immunophilin chaperones. Endocr Rev 18: 306-360.

Pratt WB, Toft DO. 2003. Regulation of signaling protein function and trafficking by the hsp90/hsp70-based chaperone machinery. Exp Biol Med 228: 111-133.

Prodromou C, Roe SM, O’Brien R, Ladbury JE, Piper PW, Pearl LH. 1997. Identification and structural characterization of the ATP/ADP-binding site in the Hsp90 molecular chaperone. Cell 90: 65-75.

Qu Y, Dai B, Ye D, Kong Y, Chang K, Jia Z, Yang X, Zhang H, Zhu Y, Shi G. 2015. Constitutively active AR-V7 plays an essential role in the development and progression of castration-resistant prostate cancer. Sci Rep 5: 7654.

Quayle SN, Mawji NR, Wang J, Sadar MD. 2007. Androgen receptor decoy molecules block the growth of prostate cancer. Proc Natl Acad Sci 104: 1331-1336.

Rachez C, Freedman LP. 2001. Mediator complexes and transcription. Curr Opin Cell Biol 13: 274-280.

Ramos-Esquivel A, Fernandez C, Zeledon Z. 2016. Androgen-deprivation therapy plus chemotherapy in metastatic hormone-sensitive prostate cancer. A systematic review and meta-analysis of randomized clinical trials. Urol Oncol 34: 335.e9-335.e19.

Ravindranathan P, Lee TK, Yang L, Centenera MM, Butler L, Tilley WD, Hsieh JT, Ahn JM, Raj GV. 2013. Peptidomimetic targeting of critical androgen receptor-coregulator interactions in prostate cancer. Nat Commun 4: 1923.

Richter K, Haslbeck M, Buchner J. 2010. The heat shock response: Life on the verge of death. Mol Cell 40: 253-266.

Robinson D, Van Allen EM, Wu YM, Schultz N, Lonigro RJ, Mosquera JM, Montgomery B, Taplin ME, Pritchard CC, Attard G, et al. 2015. Integrative clinical genomics of advanced prostate cancer. Cell 161: 1215-1228.

Romanel A, Gasi Tandefelt D, Conteduca V, Jayaram A, Casiraghi N, Wetterskog D, Salvi S, Amadori D, Zafeiriou Z, Rescigno P, et al. 2015. Plasma AR and abirateroneresistant prostate cancer. Sci Transl Med 7: 312re310.

Saad F, Hotte S, North S, Eigl B, Chi K, Czaykowski P, Wood L, Pollak M, Berry S, Lattouf JB, et al. 2011. Randomized phase II trial of custirsen (OGX-011) in combination with docetaxel or mitoxantrone as second-line therapy in patients with metastatic castrate-resistant prostate cancer progressing after first-line docetaxel: CUOG trial P-06c. Clin Cancer Res 17: 5765-5773.

Sack JS, Kish KF, Wang C, Attar RM, Kiefer SE, An Y, Wu GY, Scheffler JE, Salvati ME, Krystek SR Jr, et al. 2001. Crystallographic structures of the ligand-binding domains of the androgen receptor and its T877A mutant complexed with the natural agonist dihydrotestosterone. Proc Natl Acad Sci 98: 4904-4909.

Sahu B, Laakso M, Pihlajamaa P, Ovaska K, Sinielnikov I, Hautaniemi S, Janne OA. 2013. FoxA1 specifies unique androgen and glucocorticoid receptor binding events in prostate cancer cells. Cancer Res 73: 1570-1580.

Salvi S, Casadio V, Conteduca V, Burgio SL, Menna C, Bianchi E, Rossi L, Carretta E, Masini C, Amadori D, et al. 2015. Circulating cell-free AR and CYP17A1 copy number variations may associate with outcome of metastatic castration-resistant prostate cancer patients treated with abiraterone. Br J Cancer 112: 1717-1724. 
M.M. Centenera et al.

Schaufele F, Carbonell X, Guerbadot M, Borngraeber S Chapman MS, Ma AA, Miner JN, Diamond MI. 2005. The structural basis of androgen receptor activation Intramolecular and intermolecular amino-carboxy interactions. Proc Natl Acad Sci 102: 9802-9807.

Scher HI, Buchanan G, Gerald W, Butler LM, Tilley WD. 2004. Targeting the androgen receptor: Improving outcomes for castration-resistant prostate cancer. Endocr Relat Cancer 11: 459-476.

Scher HI, Fizazi K, Saad F, Taplin ME, Sternberg CN, Miller K, De Wit R, Mulders P, Hirmand M, Selby B, et al. 2012 Effect of MDV3100, an androgen receptor signaling inhibitor (ARSI), on overall survival in patients with prostate cancer postdocetaxel: Results from the phase III AFFIRM study. J Clin Oncol 30: LBA1.

Scher HI, Lu D, Schreiber NA, Louw J, Graf RP, Vargas HA, Johnson A, Jendrisak A, Bambury R, Danila D, et al. 2016. Association of AR-V7 on circulating tumor cells as a treatment-specific biomarker with outcomes and survival in castration-resistant prostate cancer. JAMA Oncol 2: 1441-1449.

Scheufler C, Brinker A, Bourenkov G, Pegoraro S, Moroder L, Bartunik H, Hartl FU, Moarefi I. 2000. Structure of TPR domain-peptide complexes: Critical elements in the assembly of the Hsp70-Hsp90 multichaperone machine. Cell 101: 199-210.

Schoenmakers E, Alen P, Verrijdt G, Peeters B, Verhoeven G, Rombauts W, Claessens F. 1999. Differential DNA binding by the androgen and glucocorticoid receptors involves the second $\mathrm{Zn}$-finger and a C-terminal extension of the DNA-binding domains. Biochem J 341: 515-521.

Shaffer PL, Jivan A, Dollins DE, Claessens F, Gewirth DT. 2004. Structural basis of androgen receptor binding to selective androgen response elements. Proc Natl Acad Sci 101: 4758-4763.

Shang Y, Myers M, Brown M. 2002. Formation of the androgen receptor transcription complex. Mol Cell 9: 601-610.

Sharp A, Welti J, Blagg J, de Bono JS. 2016. Targeting androgen receptor aberrations in castration-resistant prostate cancer. Clin Cancer Res 22: 4280-4282.

Shelton SN, Shawgo ME, Matthews SB, Lu Y, Donnelly AC, Szabla K, Tanol M, Vielhauer GA, Rajewski RA, Matts RL, et al. 2009. KU135, a novel novobiocin-derived C-terminal inhibitor of the $90-\mathrm{kDa}$ heat shock protein, exerts potent antiproliferative effects in human leukemic cells. Mol Pharmacol 76: 1314-1322.

Shiota M, Bishop JL, Nip KM, Zardan A, Takeuchi A, Cordonnier T, Beraldi E, Bazov J, Fazli L, Chi K, et al. 2013. Hsp27 regulates epithelial mesenchymal transition, metastasis, and circulating tumor cells in prostate cancer. Cancer Res 73: 3109-3119.

Siegel RL, Miller KD, Jemal A. 2016. Cancer statistics, 2016. CA Cancer J Clin 66: 7-30.

Singhal H, Greene ME, Tarulli G, Zarnke AL, Bourgo RJ, Laine M, Chang YF, Ma S, Dembo AG, Raj GV, et al. 2016. Genomic agonism and phenotypic antagonism between estrogen and progesterone receptors in breast cancer. Sci $A d v$ 2: e1501924.

Solit DB, Zheng FF, Drobnjak M, Munster PN, Higgins B, Verbel D, Heller G, Tong W, Cordon-Cardo C, Agus DB, et al. 2002. 17-Allylamino-17-demethoxygeldanamycin induces the degradation of androgen receptor and HER-
$2 / n e u$ and inhibits the growth of prostate cancer xenografts. Clin Cancer Res 8: 986-993.

Steinkamp MP, O’Mahony OA, Brogley M, Rehman H, Lapensee EW, Dhanasekaran S, Hofer MD, Kuefer R, Chinnaiyan A, Rubin MA, et al. 2009. Treatment-dependent androgen receptor mutations in prostate cancer exploit multiple mechanisms to evade therapy. Cancer Res 69: 4434-4442.

Stelloo S, Nevedomskaya E, Kim Y, Hoekman L, Bleijerveld OB, Mirza T, Wessels LFA, van Weerden WM, Altelaar AFM, Bergman AM, et al. 2017. Endogenous androgen receptor proteomic profiling reveals genomic subcomplex involved in prostate tumorigenesis. Oncogene doi: 10.1038/ onc.2017.330.

Suzuki H, Sato N, Watabe Y, Masai M, Seino S, Shimazaki J. 1993. Androgen receptor gene mutations in human prostate cancer. J Steroid Biochem Mol Biol 46: 759-765.

Swinstead EE, Miranda TB, Paakinaho V, Baek S, Goldstein I, Hawkins M, Karpova TS, Ball D, Mazza D, Lavis LD, et al. 2016. Steroid receptors reprogram FoxA1 occupancy through dynamic chromatin transitions. Cell 165: 593605.

Tannock IF, de Wit R, Berry WR, Horti J, Pluzanska A, Chi KN, Oudard S, Theodore C, James ND, Turesson I, et al. 2004. Docetaxel plus prednisone or mitoxantrone plus prednisone for advanced prostate cancer. $N$ Engl J Med 351: 1502-1512.

Taplin ME, Bubley GJ, Shuster TD, Frantz ME, Spooner AE, Ogata GK, Keer HN, Balk SP. 1995. Mutation of the androgen-receptor gene in metastatic androgen-independent prostate cancer. N Engl J Med 332: 1393-1398.

Taplin ME, Montgomery B, Logothetis CJ, Bubley GJ, Richie JP, Dalkin BL, Sanda MG, Davis JW, Loda M, True LD, et al. 2014. Intense androgen-deprivation therapy with abiraterone acetate plus leuprolide acetate in patients with localized high-risk prostate cancer: Results of a randomized phase II neoadjuvant study. J Clin Oncol 32: 3705-3715.

Taylor BS, Schultz N, Hieronymus H, Gopalan A, Xiao Y, Carver BS, Arora VK, Kaushik P, Cerami E, Reva B, et al. 2010. Integrative genomic profiling of human prostate cancer. Cancer Cell 18: 11-22.

The Cancer Genome Atlas Research Network. 2015. The molecular taxonomy of primary prostate cancer. Cell 163: 1011-1025.

Tilley WD, Buchanan G, Hickey TE, Bentel JM. 1996. Mutations in the androgen receptor gene are associated with progression of human prostate cancer to androgen independence. Clin Cancer Res 2: 277-285.

Tilley WD, Marcelli M, Wilson JD, McPhaul MJ. 1989. Characterization and expression of a cDNA encoding the human androgen receptor. Proc Natl Acad Sci 86: 327-331.

Tran C, Ouk S, Clegg NJ, Chen Y, Watson PA, Arora V, Wongvipat J, Smith-Jones PM, Yoo D, Kwon A, et al. 2009. Development of a second-generation antiandrogen for treatment of advanced prostate cancer. Science 324: 787-790.

Trotta AP, Need EF, Butler LM, Selth LA, O'Loughlin MA, Coetzee GA, Tilley WD, Buchanan G. 2012. Subdomain structure of the co-chaperone SGTA and activity of its androgen receptor client. J Mol Endocrinol 49: 57-68. 
Targeting the Androgen Receptor in Prostate Cancer

van Soest RJ, van Royen ME, de Morree ES, Moll JM, Teubel W, Wiemer EA, Mathijssen RH, de Wit R, van Weerden WM. 2013. Cross-resistance between taxanes and new hormonal agents abiraterone and enzalutamide may affect drug sequence choices in metastatic castration-resistant prostate cancer. Eur J Cancer 49: 3821-3830.

Veldscholte J, Ris-Stalpers C, Kuiper GG, Jenster G, Berrevoets C, Claassen E, van Rooij HC, Trapman J, Brinkmann AO, Mulder E. 1990. A mutation in the ligand binding domain of the androgen receptor of human LNCaP cells affects steroid binding characteristics and response to anti-androgens. Biochem Biophys Res Commun 173: 534-540.

Visakorpi T, Hyytinen E, Koivisto P, Tanner M, Keinanen R, Palmberg C, Palotie A, Tammela T, Isola J, Kallioniem OP. 1995. In vivo amplification of the androgen receptor gene and progression of human prostate cancer. $\mathrm{Nat} \mathrm{Ge}$ net 9: 401-406.

Wang Q, Li W, Liu XS, Carroll JS, Janne OA, Keeton EK, Chinnaiyan AM, Pienta KJ, Brown M. 2007. A hierarchical network of transcription factors governs androgen receptor-dependent prostate cancer growth. Mol Cell 27: $380-392$

Welti J, Rodrigues DN, Sharp A, Sun S, Lorente D, Riisnaes R, Figueiredo I, Zafeiriou Z, Rescigno P, de Bono JS, et al. 2016. Analytical validation and clinical qualification of a new immunohistochemical assay for andro- gen receptor splice variant-7 protein expression in metastatic castration-resistant prostate cancer. Eur Urol 70: 599-608.

Wilding G, Chen M, Gelmann EP. 1989. Aberrant response in vitro of hormone-responsive prostate cancer cells to antiandrogens. Prostate 14: 103-115.

Williams CR, Tabios R, Linehan WM, Neckers L. 2007. Intratumor injection of the Hsp90 inhibitor 17AAG decreases tumor growth and induces apoptosis in a prostate cancer xenograft model. J Urol 178: 1528-1532.

Wyatt AW, Azad AA, Volik SV, Annala M, Beja K, McConeghy B, Haegert A, Warner EW, Mo F, Brahmbhatt S, et al. 2016. Genomic alterations in cell-free DNA and enzalutamide resistance in castration-resistant prostate cancer. JAMA Oncol 2: 1598-1606.

Yap TA, Omlin A, de Bono JS. 2013. Development of therapeutic combinations targeting major cancer signaling pathways. J Clin Oncol 31: 1592-1605.

Zellweger T, Chi K, Miyake H, Adomat H, Kiyama S, Skov K, Gleave ME. 2002. Enhanced radiation sensitivity in prostate cancer by inhibition of the cell survival protein clusterin. Clin Cancer Res 8: 3276-3284.

Zhu ML, Horbinski CM, Garzotto M, Qian DZ, Beer TM, Kyprianou N. 2010. Tubulin-targeting chemotherapy impairs androgen receptor activity in prostate cancer. Cancer Res 70: 7992-8002. 


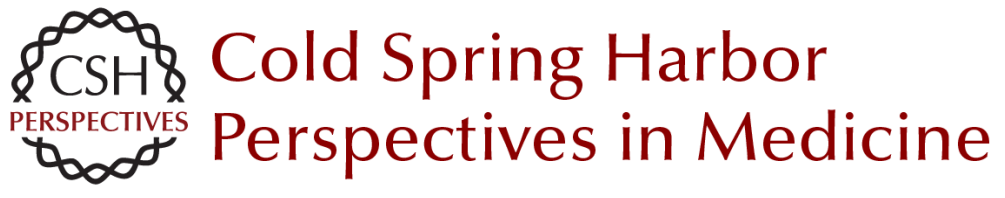

\section{New Opportunities for Targeting the Androgen Receptor in Prostate Cancer}

Margaret M. Centenera, Luke A. Selth, Esmaeil Ebrahimie, Lisa M. Butler and Wayne D. Tilley

Cold Spring Harb Perspect Med 2018; doi: 10.1101/cshperspect.a030478 originally published online March 12, 2018

\section{Subject Collection Prostate Cancer}

Anatomic and Molecular Imaging in Prostate

Cancer

Eric T. Miller, Amirali Salmasi and Robert E. Reiter

The Epidemiology of Prostate Cancer

Claire H. Pernar, Ericka M. Ebot, Kathryn M. Wilson, et al.

Prostate Stem Cells and Cancer Stem Cells Jia J. Li and Michael M. Shen

Prostate Cancer Epigenetics: From Basic

Mechanisms to Clinical Implications

Srinivasan Yegnasubramanian, Angelo M. De

Marzo and William G. Nelson

The Genomics of Prostate Cancer: A Historic

Perspective

Mark A. Rubin and Francesca Demichelis

Neuroendocrine Differentiation in Prostate

Cancer: Emerging Biology, Models, and Therapies Loredana Puca, Panagiotis J. Vlachostergios and Himisha Beltran

DNA Damage Response in Prostate Cancer Matthew J. Schiewer and Karen E. Knudsen

Transcriptional Regulation in Prostate Cancer David P. Labbé and Myles Brown
New Opportunities for Targeting the Androgen

Receptor in Prostate Cancer Margaret M. Centenera, Luke A. Selth, Esmaeil Ebrahimie, et al.

Prostate Cancer Research at the Crossroads Michael M. Shen and Mark A. Rubin

Immunotherapy for Prostate Cancer Nicholas J. Venturini and Charles G. Drake

Molecular Pathology of High-Grade Prostatic Intraepithelial Neoplasia: Challenges and Opportunities Levent Trabzonlu, Ibrahim Kulac, Qizhi Zheng, et al.

Metastases in Prostate Cancer Federico La Manna, Sofia Karkampouna, Eugenio Zoni, et al.

Genetically Engineered Mouse Models of Prostate Cancer in the Postgenomic Era Juan M. Arriaga and Cory Abate-Shen

Molecular Biomarkers in the Clinical Management of Prostate Cancer Aaron M. Udager and Scott A. Tomlins

Metabolic Vulnerabilities of Prostate Cancer:

Diagnostic and Therapeutic Opportunities Giorgia Zadra and Massimo Loda

For additional articles in this collection, see http://perspectivesinmedicine.cshlp.org/cgi/collection/ 